\begin{tabular}{|c|c|}
\hline u & $\begin{array}{c}\text { JAMBORA JOORNAL CIVIC EDOCATION } \\
\text { http://ejurnal.ung.ac.id/index.php./jacedu } \\
\begin{array}{c}\text { E-ISSN: } 2798-4818 \\
\text { P-ISSN: 2808-2249 }\end{array}\end{array}$ \\
\hline
\end{tabular}

\title{
PERAN GURU PENDIDIKAN PANCASILA DAN KEWARGANEGARAAN DALAM MENANGGULANGI MASALAH KENAKALAN REMAJA DI SEKOLAH MENEGAH ATAS NEGERI 1 BOKAT KACAMATAN BOKAT KABUPATEN BUOL SULAWESI TENGAH
}

\author{
Sartika U Agel ${ }^{1}$, Zulaecha Ngiu ${ }^{2}$, Rasid Yunus ${ }^{3}$, Yuli Adhani ${ }^{4}$ \\ Fakultas Ilmu Sosial, Universitas Negeri Gorontalo \\ sartikaugangel@gmail.com \\ zulaechangiu@gmail.com \\ rasidyunus@gmail.com \\ yuliadhani@gmail.com
}

\begin{tabular}{|c|c|}
\hline Info Artikel & Abstrak \\
\hline $\begin{array}{l}\text { Sejarah Artikel: } \\
\text { Diterima (Desember) (2021) } \\
\text { Disetujui (Desember ) (2021) } \\
\text { Dipublikasikan (Desember) } \\
\text { (2021) }\end{array}$ & $\begin{array}{l}\text { Penelitian ini untuk mengetahui bagaimana Peran Guru Pendidikan } \\
\text { Pancasila dan Kewarganegaraan dalam Menanggulangi Masalah Kenakalan } \\
\text { Remaja di Sekolah SMA negeri } 1 \text { Bokat Kecamatan Bokat kabupaten Buol dan } \\
\text { Untuk mengetahui Faktor-faktor apa saja yang Melatar Belakangi Masalah } \\
\text { kenakalan Remaja di Sekolah SMA Negeri } 1 \text { Bokat Kecamatan Bokat } \\
\text { Kabupaten. Penelitian ini menggunakan metode Pendekatan Kualitatif yaitu } \\
\text { dengan mendekripsikan data penelitian dalam bentuk kalimat-kalimat berupa } \\
\text { keterangan dan pernyataan-pernyataan dari informan sesuai dengan realita } \\
\text { dilapangan. Buol melalui hasil observasi, wawancara dan dokmentasi. Hasil } \\
\text { penelitian ini menunjuk bagaimana Peran guru PPKn dalam Menanggulangi } \\
\text { Masalah Kenakalan Remaja di Sekolah SMA Negeri } 1 \text { Bokat, Guru PPKn sudah } \\
\text { melakukan perannya bahwa sebagai pembimbing dalam kegiatan belajar } \\
\text { mengajar sangat di perlukan, selain melaksanakan tugas mengajar, mendidik } \\
\text { perilaku peserta didik supaya tidak melakukan kenakalan atau tingkah } \\
\text { lakunya melanggar norma di sekolah serta peraturan-peraturan tata tertib } \\
\text { yang sudah ditetapkan oleh pihak sekolah. Adapun faktor-faktor yang melatar } \\
\text { belakangi masalah kenakalan remaja di sekolah SMA N } 1 \text { Bokat yaitu adalah } \\
\text { a) Lingkungan masyarakat yang negatif; b) Broken home; c) Pergaulan teman } \\
\text { sebaya; d) Kurangnya perhatian orang tua. Dari keempat faktor tersebutyang } \\
\text { mempengaruhi perilaku remaja dalam lingkungan sekolah dan luar sekolah. }\end{array}$ \\
\hline
\end{tabular}

\section{PENDAHULUAN}

Pendidikan adalah suatu usaha setiap individu untuk mendapatkan ilmu dan pengetahuan. Sehingga perlunya kesadaran setiap individu untuk menempuh

\footnotetext{
${ }^{1}$ Mahasiswa PPKN UNG

2 Dosen PPKN UNG

${ }^{3}$ Dosen PPKN UNG

${ }^{4}$ Dosen PPKN UNG
} 
pendidikan. Pendidikan juga merupakan usaha sadar mengembangkan kepribadian seseorang tersebut yang berlangsung di sekolah maupun di luar sekolah.

Pendidikan merupakan kunci dalam mewujudkan cita-cita bangsa seperti yang tersirat dalam pembukaan UUD 1945 yaitu mencerdaskan kehidupan bangsa.Pendidikan menjadi perantara untuk mengembangkan dan menggali semua potensi diri yang dimiliki baik sebagai makhluk individu maupun makhluk sosial. Pendidikan umumnya diselenggarakan di sekolah sebagai lembaga pendidikan formal dengan mengikuti program-program yag terstruktur dan telah direncanakan oleh suatu lembaga pendidikan.

Ki Hajar Dewantara mengartikan pendidikan sebagai daya upaya untuk memajukan budi pekerti, pikiran serta jasmani anak, agar dapat memajukan kesempurnaan hidup yaitu hidup dan menghidupkan anak yang selaras dengan alam dan masyarakatnya.

Menurut Mappiare berlangsung antara umur 12 tahun sampai 21 tahun bagi wanita dan 13 tahun sampai dengan 22 tahun bagi pria. Remaja adalah masa peralihan dari masa kanak-kanak menuju masa dewasa yang ditandai dengan adanya perubahan aspek fisik, psikis, dan psikososial, (dalam Roman Zulkarnain:2018:27)

Dalam Undang-Undang Nomor 23 Tahun 2002 Pasal 1 ayat 1 merumuskan bahwa anak adalah seorang yang belum genap berusia 18 tahun sejak dalam kandungan. Pengkategorian remaja dikalangan masyarakat tercermin pada undang-undang ini. Dimana remaja umumnya dikenal pada usia anak sekolah di tingkat menegah pertama (SMP) hingga tingkat menengah atas (SMA) yakni berkisar umur 13-18 tahun. Dalam sudut pandang Islam pun tidak dikenal adanya penegrtian remaja. Islam memandang dua fase yakni anak dan baligh (berakal sehat atau dewasa).Dalam Islam seorang anak dapat disebut baligh bila anak tersebut sudah mampu membedakan mana yang baik dan buruk atau mengalami gejala biologis seperti mimpi basah (bagi laki-laki) dan menstruasi (bagi perempuan).

Dalam Undang-Undang Nomor 20 Tahun 2003 Tentang sistem Pendidikan Nasional Pasal 3 menyebutkan bawha:

"Pendidikan Nasional berfungsi mengembangkan kemampuan dan membentuk watak serta peradaban bangsa yang bermartabat dalam rangka mencerdaskan kehidupan bangsa, bertujuan untuk berkembangnya potensi peserta didik agar menjadi manusia yang beriman dan bertakwa kepada Tuhan yang Maha Esa, berakhlak mulia, sehat, 
berilmu, cakap, kreatif, mandiri, dan menjadi warga negara yang demokratis serta bertanggung jawab". Di Pasal 3 Undang-Undang Nomor 20 Tahun 2003 tentang sistem Pendidikan nasional dijelaskan fungsi pendidikan mengembangkan kemampuan dan membentuk watak peserta didik dalam lingkungan sekolah. Sehingga terbentuk peserta didik yang berakhlak mulia, mandiri, dan menjadi warga negara yang demokratis serta bertanggung jawab.

Secara umum pengertian, Guru adalah pendidik profesional atau orang yang memiliki tugas utamanya sebagai pengajar, pendidik, pembimbing, pelatih, dan pemberi ilmu pengetahuan kepada siswa. Guru adalah semua orang yang berwenang dan bertanggung jawab terhadap pendidikan siswa, baik secara individual ataupun kelompok, baik di sekolah maupun di luar sekolah. Guru dalam pandangan masyarakat adalah orang yang melaksanakan pendidikan di tempat-tempat tertentu tidak mesti pendidikan formal, tetapi bisa juga di masjid, di rumah dan sebagainya menurut. Guru adalah orang yang di berikan tanggung jawab sebagai pendidik di lingkungan sekolah (Dalam Widya Ariati H, 2020:7-8).

Guru harus mempunyai kepribadian yang khas yaitu guru harus ramah, sabar, menunjukkan pengertian, memberikan kepercayaan dan menciptakan suasana aman. Di sisi lain guru harus memberikan tugas, mendorong siswa untuk mencapai tujuan, menegur, menilai, dan mengadakan koreksi. Apabila seorang guru yang tidak bisa memerankan pribadinya sebagai guru, maka guru tersebut akan berpihak kepada salah satu pribadi yang akan menjadi ciri khasnya. Guru harus bisa memilah serta memilih kapan saatnya berempati kepada siswa, kapan saatnya menolak, dan guru juga harus mampu berperan ganda karena dengan berperan ganda dapat diwujudkan secara berlainan sesuai dengan situasi dan kondisi yang dihadapi nantinya.

Guru memang menempati kedudukan yang terhormat di masyarakat. Kewibawaannya yang menyebabkan guru sangat dihormati, sehingga masyarakat tidak meragukan figur guru. Masyarakat yakin bahwa hanya guru yang dapat mendidik anak mereka menjadi orang yang berkepribadian mulia.

Kepercayaan yang diberikan oleh masyarakat, maka di pundak guru diberikan tugas dan tanggung jawab yang berat. Melaksanakan tugas sebagai guru memang berat, tapi lebih berat lagi melaksanakan tanggung jawab. Sebab tanggung jawab guru tidak hanya sebatas di sekolah, tetapi juga di luar sekolah. Pembinaan yang diberikan pun tidak hanya secara kelompok, tetapi juga secara individual. Kompetensi guru dan 
keefektifitasan termasuk tanggung jawab untuk membantu semua siswa untuk sukses di masa sekarang maupun di masa yang akan datang, walaupun murid ada yang berasal dari keluarga yang kurang mampu dan latar belakang yang berebeda-beda. Masyarakat memandang guru adalah pengajar profesional yang bervariasi, masyarakat percaya bahwa guru yang kompeten dan efektif adalah kunci yang sangat penting untuk sistem pendidikan. Seorang guru di harapkan mahir dalam strategi intruksi, materi kurikulum, metode-metode pembelajaran, teknologi pendidikan yang tinggi dan teknik manajemen ruang kelas. Guru juga di harapkan memiliki pengertian yang menyeluruh tingkat kemajuan murid yang sangat mengerti dengan isi dari yang diajarkan.

Guru sebagai penanggung jawab dalam mengontrol setiap aktivitas siswa agar dapat menciptakan siswa yang berkarakter baik dan tidak menyimpang dengan normanorma yang ada. Guru merupakan suatu komponen yang penting dalam penyelenggaraan pendidikan yang bertugas menyelenggarakan kegiatan mengajar, melatih, meneliti, mengembangkan, mengelola dan memberikan pelayanan teknis dalam bidang pendidikan.

Seorang guru tugasnya mengajar, maka dia harus mempunyai wewenang mengajar berdasarkan kualifikasi sebagai tenaga pengajar dan sebagai tenaga pengajar guru harus mempunyai kemampuan profesional dalam proses belajar mengajar. Guru sebagai pendidik, yaitu guru sanggup mengarahkan dan memberikan teladan kepada anak didiknya agar sang anak mengikuti norma maupun aturan yang berlaku di masyarakat. Guru sebagai pembimbing yaitu guru sanggup membimbing agar seluruh anak didiknya tetap berada di jalur yang tepat selama kegiatan belajar mengajar berlangsung di jalur formal dan non formal.

Peran guru bukan hanya sebagai pengajar, dan pendidik tetapi peran guru juga tidak kalah penting sebagai motivator yaitu guru mampu memberikan dorongan mental dan moral kepada siswa agar kedepannya, selalu memiliki semangat dan tujuan dalam belajar. Guru juga harus handal dan berani dalam menghadapi setiap masalah yang ada pada siswa. Guru sebagai administrator yaitu dimana seorang guru mengetahui perkembangan individual siswanya dan menyampaikannya kepada orang tua. Dan guru juga sebagai evaluator yaitu seorang guru berhak memberikan penilaian dan masukanmasukan untuk kemajuan siswa.

Sebagai guru PPKn memiliki peran yang cukup luar biasa yaitu bukan hanya mentransfer ilmu tetapi memiliki tugas sebagai membentuk karakter siswa untuk 
menjadikan generasi yang berkualitas, agar siswa dapat memiliki potensi pribadi yang baik sesuai dengan pelajaran PPKn dalam menciptakan moral dan berpartisipasi untuk negara. Guru sebagai demonstrator yaitu guru dituntut untuk menguasai materi pelajaran yang akan diajarkan kepada siswa dan mengembangkannya. Guru juga dituntut mampu memberikan informasi kepada siswa salah satu yang harus diperhatikan oleh guru bahwa ia sendiri adalah pelajar, ini berarti bahwa guru harus belajar terus menerus Usman (dalam Widya Ariati H, 2020:10).

Istilah baku tentang kenakalan remaja dalam konsep psikologi adalah Juveniledelinquency. Secara etimologis dapat dijabarkan bahwa Juvenile berarti anak, sedangkan Delinquency berarti kejahatan. Dengan demikian, pengertian secara etimologis adalah kejahatan anak. Jika menyangkut subjek atau pelaku, maka JuvenileDelinquency menjadi anak penjahat atau anak jahat. Delinquency itu selalu mempunyai konotasi serangan, pelanggaran, kejahatan dan keganasan yang dilakukan oleh anak-anak dibawah usia 22 tahun. Huadvuad Hasan (dalam Nenda Muslihah, 2016:24) mengatakan bahwa Delinquency adalah perbuatan anti sosial yang dilakukan orang dewasa dikualifikasikan sebagai tindak kejahatan.

Pengertian secara etimologis telah mengalami pergeseran, akan tetapi hanya meyangkut aktivitasnya, yakni istilah kejahatan (Delinquency) menjadi kenakalan. Dalam perkembangan selanjutnya pengertian subjek atau pelakunya pun mengalami pergeseran. Ada beberapa ahli dalam bidang Juveniledelinquency memberikan definisi diantaranya psikolog Drs Bimowalgito merumuskan arti selengkapnya dari "Juvenile delinquency" yakni : setiap perbuatan yang bila dilakukan oleh orang dewasa, maka perbuatan itu merupakan kejahatan, jadi perbuatan yang melawan hukum yang dilakukan oleh anak, khususnya anak remaja. Istilah yang sering terdengar dan lazim dipergunakan dalam media masa adalah kenakalan remaja atau sering juga dipergunakan istilahkejahatan anak. Istilah kenakalan remaja sering ditafsirkan dengan kenakalan yang tertuang dalam Pasal 489 KUHP.

M.Gold dan J.Petronio (dalam Nenda Muslihah, 2016:24) menyatakan kenakalan anak adalah tindakan oleh seseorang yang belum dewasa yang sengaja melanggar hukum yang diketahui oleh anak itu sendiri bahwa jika perbuatannya itu sempat diketahui oleh petugas hukum ia bisa kena hukuman.

Kartono, ilmuan sosiologi Tangkudung "kenakalan remaja atau dalam bahasa inggris dikenal dengan istilah Juveniledelinquency merupakan gejala patologis sosial pada 
remaja yang disebabkan oleh satu bentuk pengabaian sosial. Akibatnya, mereka mengembangkan bentuk perilaku yang menyimpang". Sedangkan istilah kenakalan remaja (Juvenile delinquency mengacu pada suatu yang rentang yang luas, dari tingkah laku yang tifdak dapat diterima secara sosial misalnya bersikap berlebihan di sekolah sampai pelanggaran status seperti melarikan diri, hingga tindak kriminal misalnya pencurian. Kenakalan reamaja merupakan suatu tindakan yang disebabkan oleh faktor sosial. Penyebab sosiologis memiliki pengertian kenakalan remaja adalah sebuah tindakan tang tidak timbul sendiridalam diri individu tetapi ada faktor ekternal yang mnyebabkan remaja jatuh dalam perbuatan tersebut. Berdasarkan pengertian diatas, dalam pengertian Juveniledlinquency atau kenakalan remaja ialah perbuatan/kejahatan/pelanggaran yang dilakukan oleh anak remaja yang bersifat melanggar hukum, anti sosial, anti susial, dan menyalahi norma-norma agama.

\section{METODELOGI PENELITIAN}

Pendekatan penelitian yang digunakan dalam penelitian ini adalah pendekatan kualitatif. Penelitian kualitatif sering disebut metode penelitian naturalistik karena penelitiannya dilakukan pada kondisi yang alamiah (natural setting), disebut juga sebagai metode etnographi, karena pada awalnya metode ini lebih banyak digunakan untuk penelitian bidang antropologi budaya. Disebut sebagai metode kualitatif karena data yang terkumpulkan dan analisisnya lebih bersifat kualitatif.

Berdasarkan pokok permasalahan yang telah dikemukakan, maka penelitian ini menggunakan metode deskriptif. Penelitian deskriptif merupakan penelitian yang dimaksud untuk menyelidiki keadaan, kondisi, atau hal lain-lain yang sudah disebutkan, yang hasilnya dipaparkan dalam bentuk laporan penelitian. Metode penelitian deskriptif merupakan gambaran secara sistematis terhadap fakta-fakta secara akurat. Pembahasan hasil penelitian menggunakan teknik penyajian dengan memaparkan hubungan antara fenomena berdasarkan rumusan masalah dalam penelitian (dalam Risi Dayatul Adyani 2018:36).

\section{HASIL PENELITIAN DAN PEMBAHASAN}

\section{Peran Guru PPKn Dalam Menanggulangi Masalah Kenakalan Remaja Di Sekolah.}

Tugas dan peran guru, tugas pendidik; guru lebih mudah mendidik, mengajar, melatih, mengevaluasi dan terus memperbaiki sampai siswa pada jenjang sekolah 
lanjutannya, karena bagaimanapun proses ini harus dilakukan oleh pendidik sebagai bentuk proses kehidupan dalam pendidikan. Sebagai guru PPKn memiliki peran yang cukup luar biasa yaitu bukan hanya mentransfer ilmu tetapi memiliki tugas sebagai membentuk karakter siswa untuk menjadikan generasi yang berkualitas, agar siswa dapat memiliki potensi pribadi yang baik sesuai dengan pelajaran PPKn dalam menciptakan moral dan berpartisipasi untuk negara.

Berikut hasil wawancara penulis bersama guru PPKn mengenai bagaimana peran guru PPKn dalam menanggulangi kenakalan remaja.

a. Guru sebagai Pembimbing

Peran Guru Pendidikan Pancasila dan Kewarganegaraan sebagai pembimbing dan membina dalam kegiatan belajar mengajar sangat diperlukan. Selain mengajar siswa yang tidak kalah pentingnya adalah mendidik perilaku siswa agar tidak melakukan pelanggaran atau kenakalan-kenakalan yang terjadi di SMA Negeri 1 Bokat.

b. Peran guru sebagai agen moral

Peran Guru Pendidikan Pancasila dan Kewarganegaraan sebagai guru PPKn dalam membentuk karakter dalam diri siswa agar tidak malakukan kenakalan dan menjadikan siswa itu lebih baik lagi. Selain membentuk karakter siswa tersebut harus melakukan dalam menanamkan nilai-nilai moral pada siswa dan apa saja kendala yang dihadapi oleh guru PPkn dalam menanamkan moral pada siswa di SMA Negeri 1 Bokat.

\section{Faktor-Faktor Yang Melatar Belakangi Guru PPKn, Kepala Sekolah, Dalam Menanggulangi Masalah Kenakalan Remaja}

Bimbingan atau pembinaan dari guru tidak cukup untuk mencegah kenakalan yang di lakukan oleh siswa, perlu kesadaran dari siswa itu sendiri untuk tidak melakukan kenakalan. Adapun faktor-faktor yang melatar belakangi guru PPKn dan kepala sekolah dalam menanggulangi masalah kenakalan remaja di SMA Negeri 1 Bokat.

\section{a. Lingkungan Masyarakat yang Negati}

Seperti yang dikemukakan oleh Kartono adalah perasan rendah diri ini dapat melemahkan fungsi berfikir, intelektual dan kemauan remaja. Semakin kuat perasaan inferior remaja dan semakin tidak terkontrol, dampaknya semakin menghambat dan melumpuhkan kehidupan jiwani remaja, melumpuhkan pola daya adaptasi anak dalam masyarakat ramai, sebagai akibat jauhnya remaja melakukan reaksi yang over misalnya over reaksi, over compensatie, kenakalan, menjadi ekplosif dan gemar kerkelahi dan melakukan kekerasan (dalam Hidayati, 2016:35). 


\section{a. Broken Home}

Meskipun perceraian ialah permasalahan orang tua tetapi ada baiknya orang tua juga memberikan pengertian terkait perceraian yang terjadi karena penelitian mengatakan bahwa remaja merasa terjebak dalam situasi perceraian tersebut sehingga terjadi hubungan orang tua dan anak yang melemah dan kecemasan dalam menghadapi perubahan (Putri dkk, 2020:6)

\section{b. Pergaulan teman sebaya}

Seperti yang dikemukakan oleh Sudarwan berpendapat bahwa teman sebaya dapat memberikan daampak positif pada motivasi akademik anak. Karena kelompok sebaya yang memberikan pengaruh positif berupa dorongan untuk semangat belajar. Selain itu, teman sebaya juga dapat menawarkan pada anak-anak dan remaja untuk mengembangkan berbagai macam bentuk keterampilan sosial seperti, kepemimpinan, berbagi, kerja sama tim, dan empati. Dengan teman sebaya seorang anak dapat menemukan jati diri mereka (Dalam Rizka Wulandari 2017:17-18).

\section{c. Kurangnya perhatian orang tua}

Dari keluargalah anak mendapatkan pendidikan dan kasih sayang yang dibutuhkan oleh anak untuk bekal di kehidupannya. Kasih sayang yang diberikan keluarga kepada anak-anak akan menimbulkan mental yang sehat bagi anak. "kurangnya kasih sayang akan menimbulkan emosional insecurity. Demikian juga sikap keras, kejam, acuh tak acuh akan menyebabkan hal yang serupa". Anak yang memiliki mental yang sehat akan hidup dengan bahagia, nyaman, dan aman (Dalam Ristina Dwi utami 2015:1).

\section{E. Kesimpulan}

Berdasarkan hasil penelitian yang telah dilakukan oleh penulis mengenai " Peran Guru PPKn Dalam Menanggulangi Masalah Kenakalan Remaja Di SMA Negeri 1 Bokat”. Maka kesimpulan dari hasil penelitian tersebut dapat diuraikan sebagai berikut :

1. Peran guru PPKn dalam menanggulangi masalah kenakalan remaja di sekolah SMA Negeri 1 Bokat maka Kenakalan yang dilakukan oleh siswa dapat mengganggu orangorang yang ada disekitar mereka apakah akan merugikan diri sendiri, keluarga atau orang lain. Sebagaimana yang sudah dikemukakan oleh 4 orang siswa bahwa melakukan kenakalan yang tidak sesuai dengan peraturan-peraturan yang tidak sesuai dengan norma dan sudah melanggar peraturan tata tertib sekolah yang sudah di tetapkan oleh pihak sekolah, guru PPKn juga mengatakan bahwa sebagai 
pembimbing dalam kegiatan belajar mengajar sangat di perlukan, selain melaksanakan tugas mengajar, melatih yang tidak kalah penting yang dimana mendidik perilaku siswa supaya tidak melakukan kenakalan atau tingkah lakunya tidak melanggar norma-norma di sekolah dan peraturan-peraturan tata tertib sekolah yang sudah ditetapkan oleh pihak sekolah, agar teman-teman lainnya tidak terpengaruh dengan teman-teman yang nakal.

2. Adapun faktor-faktor yang melatar belakangi guru PPKn dalam menanggulangi masalah kenakalan remaja adalah sebagai berikut yaitu: a). Lingkungan masyarakat yang negatif, b). Broken home, c). Pergaulan teman sebaya, d). Kurangnya perhatian orang tua. Dari keempat faktor tersebut yang mempengaruhi perilaku remaja dalam lingkungan sekolah dan luar sekolah.

\section{DAFTAR PUSTAKA}

Adab. 2020. Guru dan Pendidikan Karakter. Indramayu. CV Adanu Abimata Jawara Zifatama. 2019. Deteksi Dini Potensi Kenekalan Remaja (Jufenile Delinquency)dan Solusi. Sidoarjo. Hak Cipta Laning Dwi Vina. 2018. Kenakalan Remaja dan Penanggulangannya. Cempaka Putih PT Latipun. 2020. Konselin Kelompok dan Perilaku Anti Sosial: Pengaruh Konselin Kelompok Terhadap Penurunan Perilaku Anti Sosial Pada Remaja di Lembaga Pemasyarakatan Anak. Psychology Forum. Malang

Octaviani A. Shilphy. 2020. Etika Profesi Guru. Rajawali. Hak Cipta

Pianda Didi. 2018. Kinerja Guru. Jawa Barat. CV Jejak

Puspasari, Karisma Dewi, Latipun. Fasikhah, Siti Suminarti. 2020. Panduan Program Pengembangan Optimisme Pada Remaja. Malang

Putri, Ade Ayu Harisdiane. Fasikhah, Siti Suminarti. 2020. Penanganan Kepada Remaja Dengan Orang Tua Bercerai. Psychology Forum. Malang

Ridhuan Syamsu, Wahid Aliaras. 2018. Pendidikan Kewarganegaraan. University Press. Universitas Esa Unggul. Jakarta

Sugiyono. 2015. Metode Penelitian Kualitatif R\&D. Bandung. Alfabeta Umami Ida. 2019. Psikologi Remaja. IDEA Press. Yogyakarta

Yanto, Taufiq Eko. 2016. Karakteristik Peserta Didik. Pusat Pengembangan dan Kebudayaan. Jakarta

Adyani Dayatul Risi. 2018. Peran Masyarakat dalam Menangani Kenakalan Remaja. Universitas Islam Negeri Ar-Raniry, Fakultas Dakwah dan Komunikasi, Jurusan Bimbingan dan Konselin Islam

Bhenikawati Desiyani. 2017. Implementasi Pembinaan Akhlak Dalam Mengatasi kenakalan siswa SMK Muhammadiyah Salatiga. Universitas Institut Agama Islam Negeri Salatiga. Fakultas Tarbiyah dan Ilmu Keguruan.Jurusan Pendidikan Agama Islam

H. Ariati Widya. 2020. Peran Guru PPKn Dalam Meminimalisir Kenakalan Siswa tawuran di SMA Negeri 5 Medan. Universitas Muhammadiyah Sumaterah Utara, Medan. 
Fakultas Keguruan dan Ilmu Pendidikan. Jurusan Pendidikan Pancasila dan Kewarganegaraan

Muslihah Nenda. 2016. Peran Sekolah Menanggulangi Kenakalan Remaja. Universitas Islam Negeri Syarif Hidayatullah. Fakultas Ilmu Tarbiyah dan Keguruan. Jurusan Ilmu Pengetahuan Sosial

N. Wahyu Hidayati. 2016. Hubungan Harga Diri dan Konfornitas Teman Sebaya dengan Kenakalan Remaja. Universitas IKIP PGRI Pontianak. Kalimantan Barat.

Ony Eka Rahayu. 2018. Pengaruh Kondisi Orang Tua Broken Home Terhadap Motivasi Belajar Siswa dalam Mata Pelajaran Ips di SMP Negeri 1 Gondanglegi. Universitas Islam Negeri Maulana Malik Ibrahim. Fakultas Ilmu Pendidikan. Jurusan Pendidikan Ilmu Pengetahuan Sosial.

R. Dwi Utami. 2015. Pengaruh Perhatian Orang Tua Terhadap Tanggung Jawab Belajar Siswa Kelas V SD Segugus-V Kacamatan Galur Kabupaten Kulon. Universitas Negeri Yogyakarta. Fakultas Ilmu Pendidikan. Jurusan Pendidikan Prasekolah dan Sekolah Dasar.

R. Oktafia Wulandari. 2017. Pengaruh Pergaulan Teman Sebaya dan Disiplin Siswa Terhadap Hasil Belajar Mata Pelajaran Ips Kelas VIII SMP Negeri 4 Kepanjen. Universitas Islam Negeri Maulana Malik Ibrahim Malang. Fakultas Ilmu Tarbiyah dan Keguruan. Jurusan Pendidikan Ilmu Pengetahuan Sosial.

Suleman Romi. 2017. Kenakalan remaja dalam prespektif kriminologi di Desa Pilomonu, Kecamatan Mootilango, Kabupaten Gorontalo. Universitas Negeri Gorontalo. Fakultas Ilmu Sosial. Jurusan Ilmu Hukum dan Kemasyarakatan

Wulandari Oka Dasu. 2019. Peran Guru Pendidikan Kewarganegaraan dalam Mencegah Kenakalan Remaja di Sekolah. Universitas Negeri Medan, Indonesia. Fakultas Ilmu Sosial. Jurusan Pendidikan Pancasila dan Kewarganegaraan

Zulkarnain Roman. 2018. Penegakan Hukum Terhadap Kenakalan Remaja di Kabupaten Sleman. Universitas Islam Indonesia, fakultas hukum, prodi ilmu hukum 